\title{
Rb-Sr AND Sm-Nd GEOCHRONOLOGY OF THE CANA BRAVA LAYERED MAFIC-ULTRAMAFIC INTRUSION, BRAZIL, AND CONSIDERATIONS REGARDING ITS TECTONIC EVOLUTION
}

\author{
CIRO TEIXEIRA CORREIA *, VICENTE A. V. GIRARDI *, COLOMBO C. G. TASSINARI *AND HARDY JOST**
}

\begin{abstract}
RESUMO GEOCRONOLOGIA Rb-Sr E Sm-Nd DA INTR USÃO MÁFICO- ULTRAMÁFICA A CAM AD AD A DE CANA BRAVA, BRASIL, E CONSIDERAÇÕES SOBRE SUA EVOLUÇÃO TECTONNICA O complexo de Cana Brava é interpretado como um complexo estratiforme anorogênico e seu acamamento mergulha de 30 a $50^{\circ}$ para NW. O maciço é composto por cinco unidades acamadadas que contêm várias associações de fases cumulus e proporções variadas de minerais inter-cumulus. As transiçoes entre as unidades são caracterizadas por mudanças abruptas na composição destas fases. Da base para o topo, a seqüência compreende anfibolitos (PICB1) sobrepostos por serpentinitos (PICB2), metawebsteritos (PICB3) e metagabros (PICB4 and PICB5). A seqüência era originalmente formada por micrograbros, peridotitos, websteritos e gabros. Dados isotópicos indicam que o magma parental do Complexo de Cana Brava evoluiu da seguinte forma: (a) Derivação mantélica há cerca de 2,5 Ga e subseqüente residência subcrustal; (b) Intrusão na Seqüência vulcano-sedimentar de Palmeirópolis e cristalização ígnea há cerca de 2,0 Ga; (c) Metamorfismo e deformação dúctil-rúptil em ambiente compressivo a 1,3 Ga, e (d) Metamorfismo posterior e re-equilíbrio durante o Ciclo Brasiliano, a cerca de $0,77 \mathrm{Ga}$.
\end{abstract}

Palavras-chave: Cana Brava, complexo estratiforme, intrusão acamadada, máfico-ultramáfica, geocronologia

\begin{abstract}
The Cana Brava complex is an anorogenic stratiform complex, whose layers dip from $30^{\circ}$ to $50^{\circ}$ $\mathrm{NW}$. The massif is made up of five units composed of layers containing several associations of cumulus phases and variable amounts of inter-cumulus minerals. Transition between units are characterized by abrupt changes in the composition of these phases. From base to top, the sequence consists of amphibolites (PICB1), overlain by serpentinites (PICB2), metawebsterites (PICB3), and metagabbros (PICB4 and PICB5). This sequence was originally formed by microgabbros, peridotites, websterites, and gabbros. Isotopic data indicate that the parental magma of the Cana Brava complex evolved as follows: (a) Mantle derivation at about $2.5 \mathrm{Ga}$ and subsequent retention at subcrustal levels; (b) Intrusion within the Palmeirópolis volcano-sedimentary sequence and igneous crystallization at about $2.0 \mathrm{Ga}$; (c) Metamorphism and ductile-ruptile deformation under compression at about $1.3 \mathrm{Ga}$; and (d) Further metamorphic reequilibration during the Brasiliano Cycle at about $0.77 \mathrm{Ga}$.
\end{abstract}

Keywords: Cana Brava, stratiform complex, layered intrusion, mafic-ultramafic, geochronology

INTRODUCTION The mafic-ultramafic complex of Cana Brava (CBC) is about $40 \mathrm{~km}$ long and up to $14 \mathrm{~km}$ wide. Its widest portion lies in the south, where the stratigraphic sequence of the complex is best exposed. It belongs to a 300 $\mathrm{km}$ long, discontinuous, north-trending belt of mafic-ultramafic massifs (Fig. 1) that includes the southern Barro Alto and the central Niquelândia complexes. Tectonically they are part of a Paleoproterozoic rift system preserved within Archean blocks of eastern and central Brazil, or emerging within Meso- and Neoproterozoic supracrustal rocks inside the Goiás Massif or Goiás-Tocantins Massif (Nilson et al. 1994, Brito Neves et al. 1995, Pimentel et al 1996). To the east, the Cana Brava Complex partially overthrusts metassedimentary rocks of the S erra da Mesa Group (Marini et al. 1977), and to the west it comes into contact with the Palmeirópolis volcano-sedimentary sequence (Ribeiro Filho \& Teixeira 1981), where intrusive relationships are still preserved (Correia 1994). The Serra da Bota Gabbro (SBB), an eastern mafic-ultramafic satellite body of the $\mathrm{CBC}$, intrudes mylonites of the Serra da Mesa Group (Fig. 2).

This paper presents and discusses previous and unpublished Rb-Sr and Sm-Nd data of Correia (1994) together with new Sm-Nd data for the CBC. These results improve the previous geochronological knowledge of the complex obtained by Matsui et al (1976), Girardi et al. (1978), and Fuji (1989). The aim of this article is to contribute to the investigation about the evolution of the $\mathrm{CBC}$ complex and, hence, to the knowledge of the Precambrian crust in central Goiás.

GEOLOGIC SETTING OF THE CBC AND METAMORPHIC EVENTS Girardi \& Kurat (1982) pointed out that the Cana Brava massif is a differentiated magmatic body affected by successive recrystallization events. The first, attributed to a granulite facies metamorphism or to sub-solidus re-equilibration under slow cooling similar to that of granulite facies, took place at about $900^{\circ} \mathrm{C}$ and $6-7 \mathrm{~Kb}$, and resulted in granoblastic texture, lamellae exsolution in cumulus orthopyroxene and clinopyroxene, and formation of pargasitic hornblende. The second converted some of the rocks into a highgrade amphibolitic assemblage, with formation of green hornblende after clinopyroxene. The last event is of low-temperature and formed serpentinite, rodingite, and talc schist.

Correia (1994) divided the complex (Fig.2) into 5 units. From east to west and from base to top, these units comprise: (a) amphibolites with mylonitic texture, and fine-grained granoblastic gabbro lenses (PICB 1); (b) serpentinite (PICB2); (c) metawebsterite (PICB3); (d) metagabbro (PICB4), and (e) more differentiated gabbros in the top (PICB5). Field and petrographic data of the sequence indicate that it originally consisted of microgabbro, peridotite, websterite, and gabbro. Shear zones and tectonic deformation are generally parallel to the primary igneous bedding and are frequent in all units. As shown in figure 2 , a prominent shear zone cuts the complex in its southern portion along the contact between PICB4 and PICB5.

To the east, the CBC (PICB 1) overthrusts the Serra da Mesa Group metasedimentary rocks. Figueiredo et al. (1981), Drago (1982) and Leão Neto et al. (1986), interpreted the western contact of the complex with supracrustal rocks of the Palmeirópolis Sequence of Ribeiro Filho \& Teixeira (1981) as tectonic. However, Correia (1994) showed the absence of mylonite in rocks close to the contact and the abundance of xenoliths of schist, quartzite, and amphibolite of the Palmeirópolis sequence within the gabbros of PICB5, indicating 
that this unit is intrusive in the supracrustals of the Palmeirópolis sequence (Fig. 2). Many of the xenoliths show reaction rims with gabbro, where the textures indicate an advanced blastesis with formation of high-grade contact metamorphic minerals, such as orthopyroxene, garnet and rutile, developed after their previous paragenesis. Lens-shaped bodies of amphibolite, from a few to hundreds of meters long, also
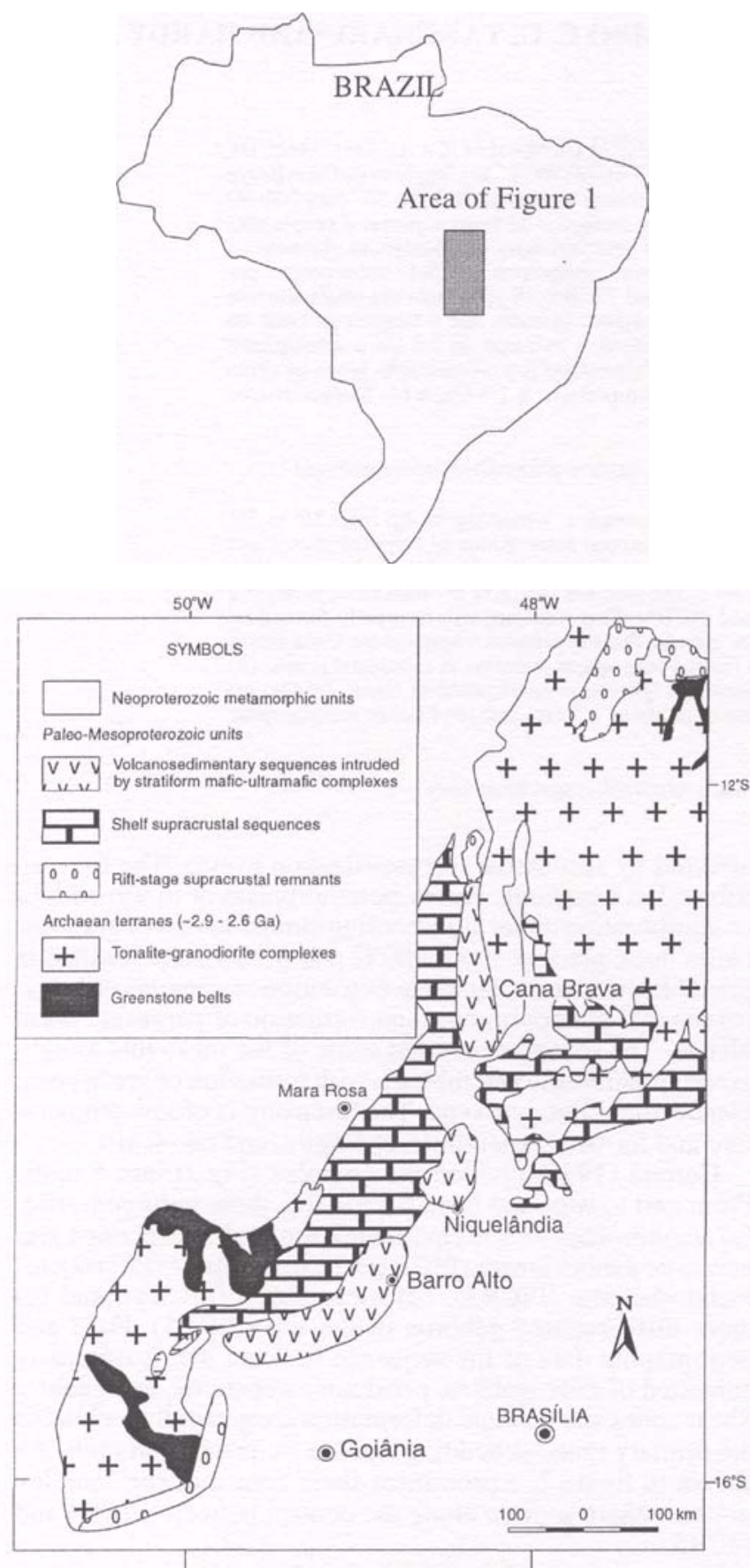

Figure 1 - Regional geological setting of the Cana Brava, Niquelândia and Barro Alto mafic-ultramafic layered complexes, Central Brazil. (A) - Paleo- to Mesoproterozoic rift systems of eastern and central Brazil according to Brito Neves et al. (1995). (B) Paleo- to Mesoproterozoic geologic units of central Brazil(this paper).

Figura 1 - Enquadramento geológico regional dos complexos acamadados máfico-ultramáficos de Cana Brava, Niquelândia e Barro Alto, Brazil Central

(A) sistema de rifts do paleo- a mesoproterozoico do Brasil oriental e central (modificado de Brito Neves et al. 1995). (B) - Unidades geológicas do Paleoa Mesoproterozoico da região central do Brasil (este artigo). occur within the PICB4 and PICB5 units. The lenses follow the general orientation of the enclosing gabbro, but have a more complex metamorphic foliation, locally discordant to that of the country-rock. These amphibolites are made up of green hornblende and frequently have borders containing large poikilitic garnets of contact metamorphism, up to 5 to $12 \mathrm{~cm}$ in diameter. Therefore, the amphibolite lenses are interpreted by Correia (1994) to be xenoliths of the Palmeirópolis sequence rocks. Girardi \& Kurat (1982) included these amphibolites in the $\mathrm{CBC}$ complex, and interpreted them as the result of recrystallization of gabbros during the second metamorphic event. Brown and green hornblende formed after clinopyroxenes in the mafic rocks is atributed by Correia (1994) to the same metamorphic event, and not to successive recrystallizations.

These observations lead to a reinterpretation of the $\mathrm{CBC}$ metamorphic events. These events are as follows:

First recrystallization after magmatic emplacement under high temperature as suggested by Girardi \& and Kurat (op. cit.)

Metamorphism under compression and tectonic transport, formation of mylonites in the eastern border of the complex, and of brown or brownish pargasitic amphibole in the mafic units. Green hornblende of the gabbros could have formed after the metamorphic peak, under less intense conditions, or during the third metamorphic event;

Metamorphism of rocks of PICB1, PICB2, and PICB3, under low temperature and close to the main thrust faults of the eastern border of the complex and, therefore, more susceptible to the influx of hidrothermal fluids.

GEOCHRONOLOGY Previous Results Until 1989 the only available geochronological data of the CBC

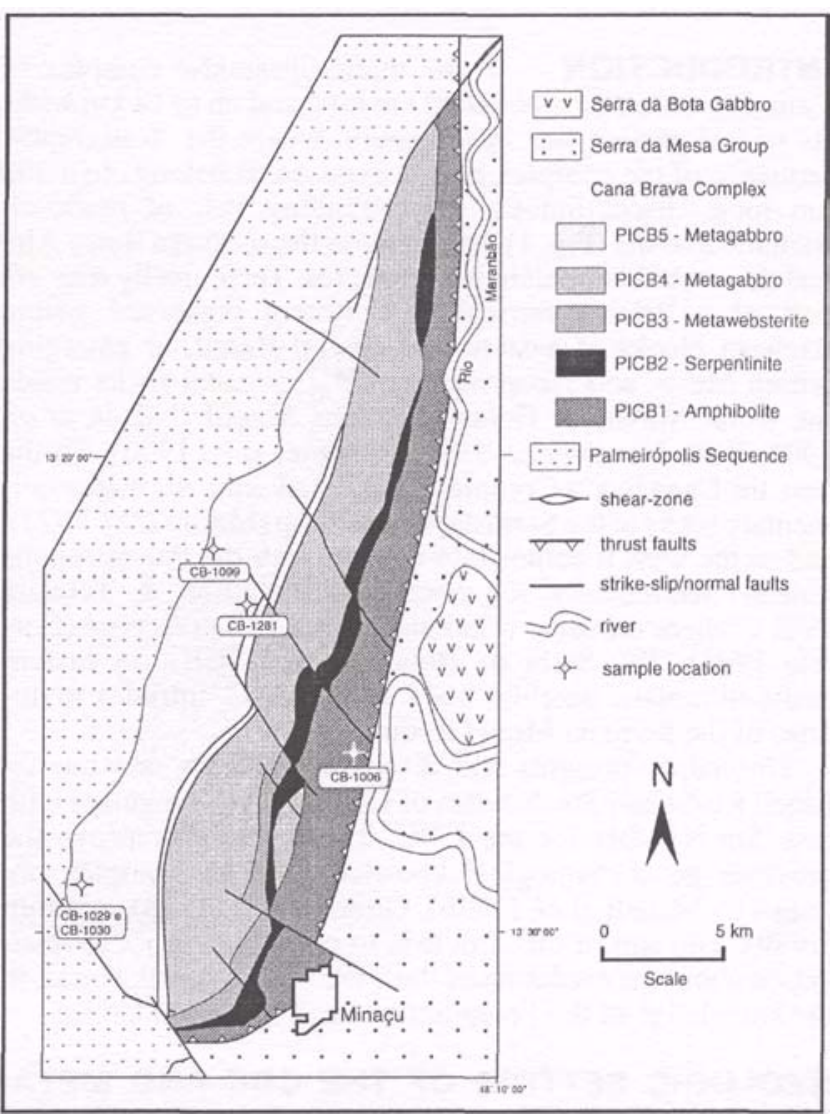

Figure 2 - Geologic map of the Cana Brava mafic-ultramafic complex, Central Brazil (simplified from Correia 1994).

Figura 2 - mapa geológico simplificado do complexo márifo-ultrmáfico de Cana Brava (simplificado de Correia 1994). 
were published by Matsui et al. (1976) and Girardi et al. (1978). The first paper reports two Ar-Ar whole-rock isochrons which yield ages of 1,925 $\pm 110 \mathrm{Ma}$ and $475 \pm 15 \mathrm{Ma}$, and several conventional $\mathrm{K}-\mathrm{Ar}$ ages distributed within the 3,950 Ma and $480 \mathrm{Ma}$ time interval. The second article includes $\mathrm{Rb}-\mathrm{Sr}$ and $\mathrm{K}-\mathrm{Ar}$ age determinations of rocks both from the eastern and western borders of the complex. The K-Ar data fits into the interval of the previous paper. However, the $\mathrm{Rb}-\mathrm{Sr}$ data define two isochronic lines. The older, containing samples from the western border, yields an age of $1,157 \pm 150 \mathrm{Ma}$ ( $R o=0.7040 \pm 0.0020)$, while the younger, including samples of the eastern border, yields an age of $644 \pm 27 \mathrm{Ma}$ (Ro = $0.7359 \pm 0.0026$ ). Girardi et al. (op.cit.) interpreted the 1,157 $\mathrm{Ma} \mathrm{Rb}-\mathrm{Sr}$ age as related to the amphibolite fades metamorphism of the western border of CBC. These rocks are now interpreted to be part of the Palmeirópolis Sequence.

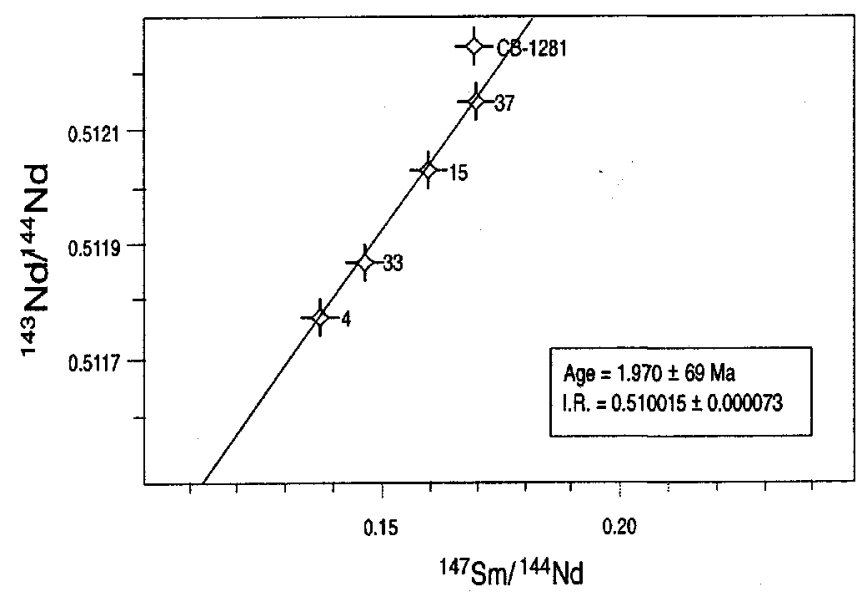

Figure 3 - Sm-Nd total-rock isochronic diagram of the Cana Brava Complex obtained by Fugi (1989). Sample CB-J281 of this paper was added to the diagram $f$ or comparison. Figura 3 - Diagrama isocrônico Sm-Nd em rocha total do Complexo de Cana Brava obtido por Fugi (1989). A amostra CB-1281 do presente artigo foi adicionada ao diagrama para comparação.
Fugi (1989) obtained two Sm-Nd isochronic ages for samples from the CCB and the Serra da Bota Gabbro (SBB). The first yielded an age of 1,970 $\pm 69 \mathrm{Ma}$ (Table I and Fig. 3), The end values lie between +0.46 and -1.90 , calculated for 1.97 $\mathrm{Ga}$, and clearly indicate that the magmatic event occurred very close in time to the mantle differentiation. The second isochron defined an age of $1,088 \pm 18 \mathrm{Ma}$. These ages correspond to the crystallization of the $\mathrm{CCB}$ and the $\mathrm{SBB}$, respectively.

Sample Selection Five quite fresh metagabbro samples (CB-1006, 1029, 1030, 1099, and 1281) of the CBC located as shown in figure 2, were collected for new geochronological determinations. Sample CB-1006 belongs to the PICB1 unit, and consists of a fine-grained metagabbro with orthopyroxene, clinopyroxene, plagioclase, and opaque minerals. The remaining samples belong to the PICB5 unit. CB-1029 is a medium-grained metadiorite with plagioclase, clinopyroxene, orthopyroxene, hornblende, biotite, garnet, and opaque minerals. CB-1030 is a medium-grained metagabbro with plagioclase, clinopyroxene, orthopyroxene, biotite, quartz, and opaque minerals. CB-1099 is a medium-grained metagabbro with plagioclase, clinopyroxene, orthopyroxene, hornblende, biotite, quartz, apatite, and opaque minerals. CB-1281 is a coarse-grained metagabbro with relicts of the original igneous texture, composed of clinopyroxene, orthopyroxene, plagioclase, amphibole, biotite, and opaque minerals. Xenoliths of the Palmeirópolis Sequence where found in the same outcrops of CB-1029 and CB-1030.

ANALYTICAL PROCEDURES Rb-Sr Analysis $\mathrm{Rb}$ and $\mathrm{Sr}$ contents and $\mathrm{Rb} / \mathrm{Sr}$ ratios were determined by $\mathrm{X}$-Ray fluorescence on powders by means of a Philips PW-1380/00 automatic spectrometer. Samples with low $\mathrm{Rb}$ and $\mathrm{Sr}$ contents (2ppm), were re-analyzed by isotopic dilution technique, using ${ }^{85} \mathrm{Rb}$ and ${ }^{84} \mathrm{Sr}$ spikes. The samples were dissolved with $\mathrm{HF}+\mathrm{HNO}_{3}$ overnight at $65^{\circ} \mathrm{C}$, and the $\mathrm{Sr}$ purified using a conventional ion exchange column with AG50WX8 cation exchange resin (200-400\#) as described, with some modifications, in Kawashita (1972). Sr isotopic analyses were carried out on a fully automated VG ISOMASS 354 mass spectrometer. The $\mathrm{Sr}$ was loaded on a single Ta filament with phosphoric acid. The ${ }^{87} \mathrm{Sr} /{ }^{86} \mathrm{Sr}$ ratios were corrected for mass fractionation by normalizing to a value of 0.1194 for $\mathrm{Sr} / \mathrm{Sr}$. During the period of this work, six analyses of the NBS-987 standard averaged $0.71026 \pm 0.00002$ (Is). Procedural blanks for $\mathrm{Sr}$

Table 1 - Sm $\mid$ Nd analytical data of the Cana Brava Complex PICB5 Unit.

Tabela 1 - Dados analíticos Sm/Nd da Unidade PICB5 do Complexo de Cana Brava

\begin{tabular}{|l|l|c|c|c|c|c|c|}
\hline \multicolumn{1}{|c|}{ Sample/Material } & \multicolumn{1}{|c|}{ Lab/N ${ }^{\circ}$} & $\begin{array}{c}\mathrm{Sm} \\
(\mathrm{ppm})\end{array}$ & $\begin{array}{c}\mathrm{Nd} \\
(\mathrm{ppm})\end{array}$ & ${ }^{147} \mathrm{Sm} /{ }^{144} \mathrm{Nd}$ & ${ }^{143} \mathrm{Nd} /{ }^{144} \mathrm{Nd}$ & $\begin{array}{c}\varepsilon_{\mathrm{Nd}} \\
(1.97 / 1.35 \mathrm{Ga})\end{array}$ & $\begin{array}{c}\mathrm{T}_{\mathrm{Dm}} \\
(\mathrm{Ga})\end{array}$ \\
\hline CB-1281-Pyroxene & CPGeo- & 0.9 & 2.9 & $0.1819 \pm 0.0001$ & $0.51235 \pm 0.00002$ & & \\
CB-1281-Plagioclase & CPGeo- & 0.1 & 1.0 & $0.0763 \pm 0.0001$ & $0.51185 \pm 0.00004$ & & \\
CB-1281-Whole Rock & CPGeo- & 0.7 & 2.4 & $0.1691 \pm 0.0001$ & $0.51232 \pm 0.00003$ & $+0.46 /-1.58$ & 2.30 \\
CB-1281-Whole Rock & La Jolla* & - & - & $0.1678 \pm 0.0001$ & $0.51227 \pm 0.00004$ & $-0.19 /-2.34$ & 2.38 \\
CB-1281-Plagioclase & La Jolla* & - & - & $0.0609 \pm 0.0001$ & $0.51172 \pm 0.00004$ & & \\
CB-1281-Biotite & La Jolla* & - & - & $0.1773 \pm 0.0001$ & $0.51232 \pm 0.00004$ & & \\
CB-4-Whole Rock & Kyoto Univ.** & 3.75 & 16.55 & 0.1368 & $0.51180 \pm 0.0006$ & $-1.52 /-6.16$ & 2.36 \\
CB-15-Whole Rock & Kyoto Univ.** & 0.97 & 3.71 & 0.1586 & $0.51208 \pm 0.0003$ & $-1.57 /-4.46$ & 2.49 \\
CB-33-Whole Rock & Kyoto Univ.** & 8.13 & 33.68 & 0.1460 & $0.51190 \pm 0.0004$ & $-1.90 /-5.79$ & 2.44 \\
CB-37-Whole Rock & Kyoto Univ.** & 1.96 & 6.97 & 0.1688 & $0.51220 \pm 0.0002$ & $-1.81 /-3.88$ & 2.63 \\
\hline
\end{tabular}

\footnotetext{
* Analyses by Mercedes D. Vergara

** Fugi (1989)
} 
Table 2 - Rb/Sr analytical data of the Cana Brava complex

Tabela 2 - Dados analíticos $\mathrm{Rb} / \mathrm{Sr}$ do Complexo de Cana Brava

\begin{tabular}{|l|l|c|c|l|l|}
\hline \multicolumn{1}{|c|}{ Sample/material } & Laboratory & $\begin{array}{c}\mathrm{Rb} \\
\mathrm{ppm}\end{array}$ & $\begin{array}{c}\mathrm{Sr} \\
\mathrm{ppm}\end{array}$ & $\mathrm{X}={ }^{87} \mathrm{Rb} /{ }^{86} \mathrm{Sr}$ & \multicolumn{1}{|c|}{$\mathrm{Y}^{87} \mathrm{Sr}{ }^{86} \mathrm{Rb}$} \\
\hline CB 1006/gabbro & CPGeo* & 0.3 & 59.4 & $0.016 \pm 0.001$ & $0.71772 \pm 0.00061$ \\
$\mathrm{CB}$ 1029/gabbro & CPGeo* $^{*}$ & 75.5 & 209.4 & $1.047 \pm 0.021$ & $0.73642 \pm 0.00022$ \\
$\mathrm{CB}$ 1030/gabbro & CPGeo* $^{*}$ & 75.7 & 132.4 & $1.663 \pm 0.028$ & $0.75003 \pm 0.00036$ \\
$\mathrm{CB}$ 1099/gabbro & CPGeo* & 101.8 & 285.6 & $1.034 \pm 0.017$ & $0.73693 \pm 0.00018$ \\
CB 4/gabbro & Kyoto & 43.75 & 156.8 & 0.80980 & 0.739746 \\
& Univ.** & & & & \pm 0.000044 \\
CB 15/gabbro & Kyoto & 0.781 & 76.07 & 0.02973 & $0.716722 \pm$ \\
& Univ.** & & & & 0.000030 \\
CB 37/pyroxenite & Kyoto & 0.8885 & 65.98 & 0.03905 & $0.718336 \pm$ \\
& Univ.** & & & & 0.000060 \\
\hline
\end{tabular}

* University of S. Paulo

**(Fugi 1989)

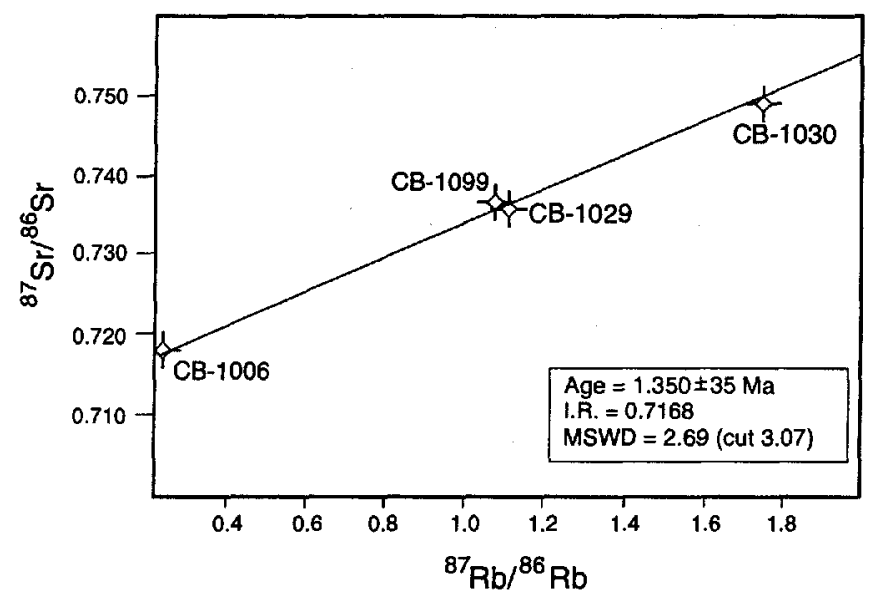

Figure 4 - Rb-Sr total-rock isochron diagram of the Cana Brava Complex.

Figura 4 - Diagrama isocrônico $\mathrm{Rb}-\mathrm{Sr}$ de rocha total do Complexo de Cana Brava.

were of the order of $1 \mathrm{ng}$. The $\mathrm{Rb}-\mathrm{Sr}$ ages were calculated using the $\mathrm{Rb}$ decay constant of $1.42 \times 10^{-11} \mathrm{a}^{-1}$. Errors reported here for age and initial ${ }^{87} \mathrm{Sr} /{ }^{86} \mathrm{Sr}$ ratios (Isr) are at the $2 \mathrm{~s}$ level. The construction of isochron diagrams was based on the method of Williamson (1968).

Sm-Nd Analysis Sm-Nd analysis followed the detailed description presented by Sato et al. (1995). About 0.10 to 0.15 $\mathrm{g}$ of sample powder were dissolved in hot $\left(60^{\circ} \mathrm{C}\right) \mathrm{HF}+\mathrm{HNO}_{3}$ in a Teflon vessel during one week. The rare earth elements (REE) were separated using cation exchange columns with AG 50W X8 resin (200-400\#), and elution with hydrochloric acid. Sm and Nd were separated from each other using columns with hydrogen di-ethylhexyl phosphate (HDEHP) supported by Teflon powder and elution with $\mathrm{HC} 1$. Sm and $\mathrm{Nd}$

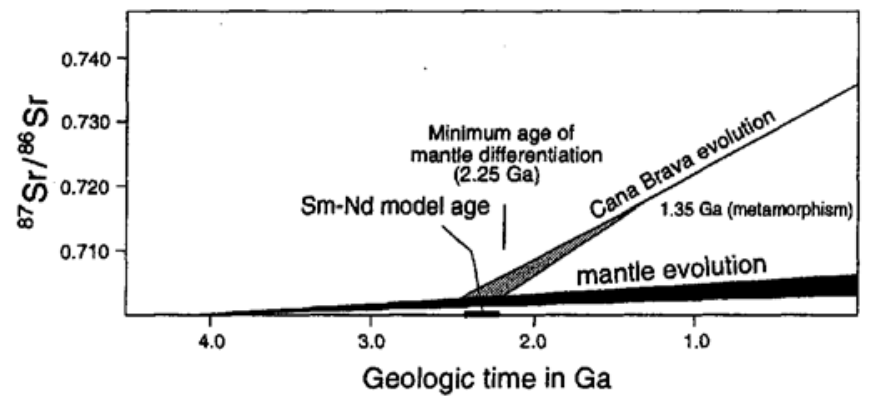

Figure 5 - Rb-Sr isotopic evolution of the Cana Brava rocks. Figura 5 - Evolução isotópica Rb-Sr das rochas de Cana Brava.

concentrations were determined by isotopic dilution techniques, using a mixed ${ }^{149} \mathrm{Sm}-{ }^{150} \mathrm{Nd}$ spike., with an $\mathrm{Nd}$ concentration of $0.0003314 \mathrm{mmol} / \mathrm{g}$ and ${ }^{149} \mathrm{Sm}$ contents of $0.004575 \mathrm{mmol} / \mathrm{g}$.

$\mathrm{Nd}$ and $\mathrm{Sm}$ were loaded as phosphates on two Ta side filaments of a triple filament assembly, with $\mathrm{Re}$ as the ionizing central filament, on a VG ISOMASS 354 fully automated mass spectrometer with five collectors. The quality of the analytical measurements by isotopic dilution techniques was evaluated using a standard ${ }^{142} \mathrm{Nd} /{ }^{144} \mathrm{Nd}$ ratio of 1.141828 . The Nd isotopic compositions were corrected for mass fractionation by normalizing to a value of 0.7219 for ${ }^{146} \mathrm{Nd} /{ }^{144} \mathrm{Nd}$.

Fourteen analysis of La Jolla and four of BCR-1 standards, yielded results of $0.511847 \pm 0.000022$ and $0.512662 \pm$ 0.000027 , respectively, during the period of this wock. Age calculations used the Sm decay constant of $6.54 \times 10^{-12} \mathrm{a}^{-1}$.

RESULTS AND DISCUSSION Tables I and II show the $\mathrm{Sm}-\mathrm{Nd}$ and $\mathrm{Rb}-\mathrm{Sr}$ data for whole-rock and mineral concentrates of the CBC samples. 


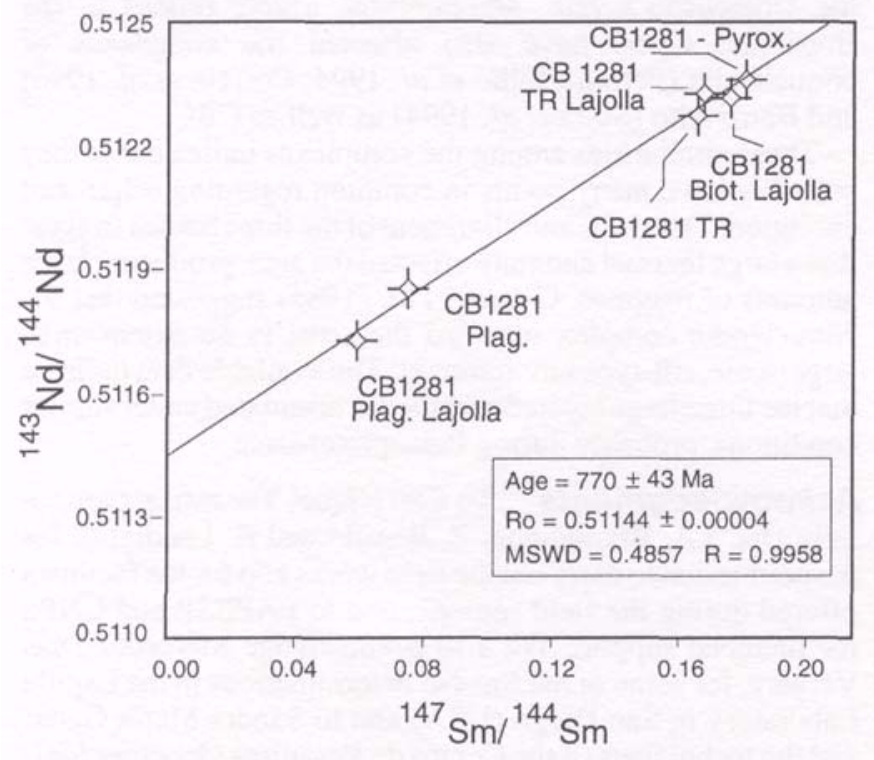

Figure 6 - Sm-Nd isochron diagram of the Cana Brava Complex from data obtained for this paper.

Figura 6 - Diagrama isocrônico Sm-Nd do Complexo de Cana Brava de dados obtidos para este artigo.

The $\mathrm{Rb}-\mathrm{Sr}$ isochronic diagram for these samples yielded an age of $1,350 \pm 35 \mathrm{Ma}$, with ${ }^{87} \mathrm{Sr} /{ }^{86} \mathrm{Sr}$ initial ratio (ISr) of 0.7168 \pm 0.0001 and MSWD value of 2.69. (Fig. 4). This age may be interpreted as due to an important metamorphic event in the $\mathrm{CBC}$, and is in close agreement, within the analytical error, with ages from $\mathrm{Rb}-\mathrm{Sr}$ isochrons obtained by Fuck et al. (1989) for the Barro Alto Complex and its country rocks, the Juscelândia vulcano-sedimentary sequence. The first yields an age of $1,266 \pm 17 \mathrm{Ma}$, with an $\mathrm{ISr}=0.73473 \pm 0.00057$ and the second, an age of $1330 \pm 66 \mathrm{Ma}$ with $\mathrm{ISr}=0.70819 \pm$ 0.00274 . These ages were attributed to metamorphism of those units, probably related to the continental collision between the proposed (Hasui \& Haralyi 1986) Porangatu and Brasilia tectonic blocks (broadly corresponding respectively to the Goiás massif and the eastern Neoproterozoic metamorphic units in Fig. 1) during the Uruaçuano Cycle (Almeida 1968), and not during the Archaean, as previously supposed by Hasui \& Haralyi (1986) . In a broad sense, these ages are also concordant with those obtained by Girardi et,al. (1978) for the western border of the CBC. Thus, the Rb-Sr data of the Barro Alto Complex and of the Juscelândia Sequence, together with the 1,090 Ma crystallization age of the undeformed SBB (Fugi 1989), strongly suggest a Mesoproterozoic metamorphic episode in the studied area..

The high Isr $(0.7168)$ of the CBC rocks probably results from assimilation of a metasedimentary component (perhaps from the Palmeirópolis Sequence) during its emplacement and with further enhancement during metamorphism at Uruaçuano times. The xenoliths and enclaves of the Palmeirópolis Sequence rocks within the PICB5 unit reinforce this interpretation. In figure 5 the regression of the $\mathrm{Sr}$ isotopic evolution curve of the complex indicates that mantle differentiation took place at a minimum age of $2.25 \mathrm{Ga}$.

The Sm-Nd method applied to six mineral concentrates and whole rock samples of the PICB5 unit define a good Sm-Nd isochron, with MSWD value $=0.4857$, yielding an age of 770 $\pm 43 \mathrm{Ma}$, with initial ${ }^{143} \mathrm{Nd} /{ }^{144} \mathrm{Nd}$ ratio of 0.51143 (Fig. 6). This age is interpreted as resulting from the latest metamorphism of the CBC. This is in close agreement with the lower concórdia intercepts obtained from $\mathrm{U}-\mathrm{Pb}$ in zircons for

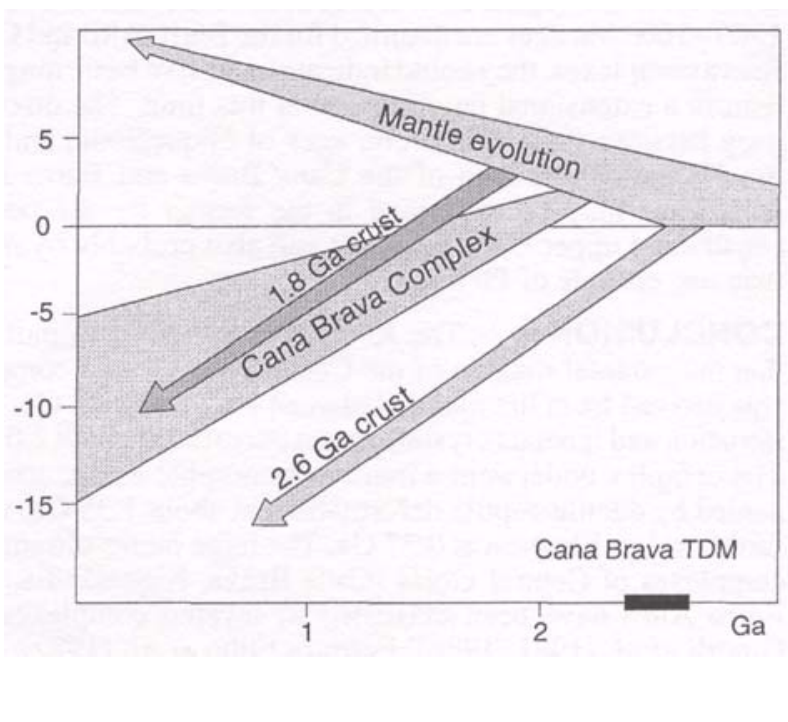

Figure 7 - Variation of the calculated ENd of the Cana Brava rocks through time.

Figura 7 - Variação de ENÜ calculado das rochas de Cana Brava ao longo do tempo.

Niquelândia (Ferreira Filho et al. 1994) and Barro Alto (Suita et al. 1994) complexes: $777 \mathrm{Ma}$ and $780 \mathrm{Ma}$, respectively.

The upper concórdia U-Pb intercept age for Barro Alto complex of 1.72-1.73 Ga determined by Suita et al. (1994) was interpreted as a minimum primary age for the intrusion. They also reported U-Pb ages of 1.29-1.35 Ga (upper intercept) and 0.77-0.82 Ga (lower intercept) for a pegmatitic gabbro from Barro Alto, interpreted as time of mafic magmatism related to the Uruaçuano Cycle or possibly post Barro Alto magmatism. The age proposed as minimum for Barro Alto intrusion is not incompatible with,the age of circa $2.0 \mathrm{Ga}$ proposed for the complexes of Cana Brava by Fugi (1989) and Niquelândia by Correia (1996). Moreover, the 1.29-1.35 Ga age of the pegmatitic gabbro from Barro Alto is in accordance with the interpretation of Fuck et al. (1989) concerning to an important tectonic event that took place in the area during Uruaçuano times.

Most of the mantle-depleted model ages TDM (De Paolo 1981) calculated for the whole-rock samples of the CBC fall within 2.35-2.50 Ga time interval (Table I). This probably corresponds to the average time during which the parental magma of the complex was extracted from the mantle.

Based on the negative values of the $\varepsilon \mathrm{Nd}$ and the decrease of the calculated $\varepsilon N d$ with increasing stratigraphic height Fugi (1989) concluded that the CBC magma underwent differential contamination by crustal rocks during crystallization. It is reasonable to suppose that the dispersion of the $\varepsilon \mathrm{Nd}$ values could also be explained by the contamination of the parental magma due to assimilation of country rocks of the Palmeirópolis Sequence just after emplacement. This is corroborated by figure 7 , where the variation of the calculated e $\mathrm{Nd}$ for $1.35 \mathrm{Ga}$ (-1.6 to -6.1$)$, shows different degrees of crustal contamination.

The available $\mathrm{Rb}-\mathrm{Sr}$ and $\mathrm{Sm}-\mathrm{Nd}$ geochronological data support the interpretation that the CBC complex formed around $2.0 \mathrm{Ga}$. A first re-equilibration after igneous crystallization, was followed by two superimposed metamorphic events, first during the Uruaçuano Cycle and second during the Brasiliano orogeny. This disagrees with the interpretation of U-Pb age of zircons of the Niquelândia Complex by Ferreira 
Filho et al. (1994), who concluded that no metamorphic event occurred in the region between 1600 and $790 \mathrm{Ma}$, and that if $1560-1600 \mathrm{Ma}$ ages are assumed for the Barro Alto and Cana Brava complexes, they could indicate extensive basic magmatism in a extensional environment at this time. The discrepancy between the U-Pb zircon ages of Niquelândia and the $\mathrm{Sm}-\mathrm{Nd}$ and $\mathrm{Rb}-\mathrm{Sr}$ data of the Cana Brava and Barro Alto complexes may be explained in the former by the poorly constrained upper $\mathrm{U}-\mathrm{Pb}$ intercept and also probably by more than one episode of $\mathrm{Pb}$ loss.

CONCLUSIONS The $\mathrm{Rb}-\mathrm{Sr}$ and $\mathrm{Sm}-\mathrm{Nd}$ data indicate that the parental magma of the Cana Brava layered complex was derived from the mantle between 2.62 and $2.25 \mathrm{Ga}$. The intrusion and igneous crystallization occurred at about $2.0 \mathrm{Ga}$. The complex underwent a main metamorphic event, accompanied by ductile-ruptile deformation, at about $1.35 \mathrm{Ga}$, with further reequilibration at $0.77 \mathrm{Ga}$. The large mafic-ultramafic complexes of Central Goiás (Cana Brava, Niquelândia, and Barro Alto) have been classified as layered complexes by Girardi et al. (1981, 1986), Ferreira Filho et al. (1992), and Oliveira \& lost (1993). The Isotopic ages now presented indicate that these complexes underwent coeval similar geologic events. An important metamorphic episode affected the Barro Alto (Fuck et al. 1989) and the CBC complexes during the Uruaçuano Cycle. Metamorphic events related to the Brasiliano Cycle have also affected the complexes of Niquelândia (Ferreira Filho et al. 1994, Correia et al. 1996) and Barro Alto (Suita et al. 1994) as well as CBC.

These similarities among the complexes indicate that they probably have many points in common regarding origin and evolution. The sizes, and alignment of the three bodies suggest that a large thermal anomaly affected the area, producing large amounts of magmas. Girardi et al. (1986) suggested that the Niquelândia complex intruded the crust in an extensional, large-scale, rift-type environment. The available data indicate that the three large layered complexes originated under similar conditions, probably during Paleoproterozoic.

Acknowledgments To Cia. Níquel Tocantins, particularly Drs. J.A. Branquinho, Z. Rosado and R. Landigraf, for the permission to carry out the field works and for the facilities offered during the field seasons, and to FAPESP and CNPq for financial support. We also acknowledge Mercedez Dias Vergara, for some of the Sm-Nd determinations in the Lajolla Laboratory in San Diego (USA) and to Sandra Maria Gabas and the technicians of the Centro de Pesquisas Geocronológicas do IGc-USP, for support during the sample preparations and analytical procedures.

\section{REFERENCES}

Almeida, F.F.M. de. 1968. Evolução tectônica do Centro-Oeste brasileiro no Proterozóico Superior. Anais da Acad. Bras, de Ciências. 40(supl.):285-295.

Brito Neves, B.B.; de Sá, J.M.; Nilson, A.A.; Botelho, N.F. 1995. A tafrogênese estateriana nos blocos paleoproterozóicos da América do Sul e processos subseqüentes. Geonomos, 3(2): 1-21.

Correia, C.T. 1994. Petrologia do Complexo Máfico-Ultramáfico de Cana Brava, Goiás. Unpublishied Doctorate Thesis. Instituto de Geociências-USP. São Paulo,153p.

Correia, C.T.; Girardi, V.A.V.; Lambert, D.D., Kinny, P.O.; Reeves, S.J. 1996. 2 Ga U-Pb (SHRIMP II) and Re-Os ages for the Niquelândia basic-ultrabasic layered intrusion, Central Goiás, Brazil. In: Cong. Bras. Geol., 39, Salvador, Anais, SBG, 6:187-189.

DePaolo, D.J. 1981. Trace elements and isotopic effects of combined wallrock assimilation and fractional crystallization. Earth. Plan. Sci. Lett., 53:189-202.

Drago, V.A. 1982. Novos conceitos sobre a evolução da região do Complexo de Cana Brava. In: Cong. Bras. Geol., 32, Salvador, Anais, SBG, 1:280-293.

Ferreira Filho, CF.; Karno, S.L.; Fuck, R.A.; Krogh, T.E.; Naldrett, A.J. 1994. Zircon and rutile U-Pb geochronology in the Niquelândia layered mafic-ultramafic intrusion, Brazil: constraints for the timing of magmatism and high-grade metamorphism. Precambrian Res., 68(3-4):241-256

Ferreira Filho, C.F.; Nilson, A.A.; Naldrett, A.J. 1992. The Niquelândia mafic-ultramafic complex, Goiás, Brazil: A contribution to the ophiolite x stratiform controversy based on new geological and structural data. Precambrian Res., 59:125-143.

Figueiredo, J. A.; Leão Neto, R.; Valente, C. R. 1981. Depósitos de sulfetos maciços de $\mathrm{Zn}$, $\mathrm{Cu}$ e $\mathrm{Pb}$ da região de Palmeirópolis, Go. In: Simp. Geol. Centro-Oeste, 1. Goiânia. Atas Goiânia SBG- Núcleos Centro-Oeste e Brasília, 422-441.

Fuck, R. A.; Brito Neves, B. B.; Cordani, U., Kawashita, K. 1989. Geocronologia Rb-Sr no complexo de Barro Alto, Goiás: Evidências de metamorfismo de alto grau e colisão continental há 1300 Ma no Brasil Central. Geochim. Brás., 3(2):125-140.

Fugi, M. Y. 1989. REE geochemistry and Sm/Nd geochronology of the Cana Brava Complex, Brazil. Umpublishied Master Thesis, Kobe Univ., Japan, 55p.

Girardi V. A. V.; Kawashita, K.; Basei, M.A. S.; Cordani, U. 1978. Algumas considerações sobre a evolução geológica da região de Cana Brava, a partir de dados geocronológicos. In: Cong. Bras. Geol., 30, Recife, Anais SBG, 1:337-348

Girardi, V.A.V.; Rivalenti, G.; Siena, F; Sinigoi, S. 1981. Precambrian Barro Alto complex of Goiás, Brazil: Bulk geochemistry and phase equilibria. N. Jb. Miner.Abh., 142(3):270-291

Girardi, V. A. V. \& Kurat, G. 1982. Precambrian mafic and ultramafic rocks of the Cana Brava complex-Brazil: mineral compositions and evolution. Rev. Bras. Geoc., 12(1-3):313-323
Girardi, V.A.V.; Rivalenti, G.; Sinigoi, S. 1986. The petrogenesis of the Niquelândia layered basic-ultrabasic complex, Central Goiás, Brazil. Jour. Petrol., 27(3):715-744.

Hasui, Y.; Haralyi, N.L.E. 1986. A megaestruturação de Goiás. In: Simp. Geolog. Centro Oeste, Goiânia, Atas, SBG, 2:120-144.

Kawashita, K. 1972. O método Rb-Sr em rochas sedimentares. Unpublished Doctor Thesis, Universidade de São Paulo.

Leão Neto, R.; Oliveira, I.W.B.; Drago, V. A. 1986. Aspectos da geologia, evolução e mineralizações, da Seqüência vulcano-sedimentar de Palmeirópolis (Grupo Palmeirópolis). In: Cong. Bras. Geol.34, Goiânia. Anais SBG, Bol.2, pp. 7-24

Marini, O. J.; Fuck, R. A.; Dardenne, M. A.; Faria, A. de. 1977. Contribuição à geologia do pré-cambriano da porção central de Goiás. Rev. Bras. Geoc., 7:304-324.

Matsui, K.; Girardi, V.A.V.; Basei, M. A. S.; Hasui, Y. 1976. Geocronologia do complexo básico-ultrabásico de Cana Brava, Goiás. In: Cong Bras Geol., 29, Ouro Preto. Anais, SBG, 4:269-277.

Nilson, A.A.; Botelho, N.F.; Ferreira Filho, C.F. 1994. Rifteamento crustal mesoproterozóico no centro-norte de Goiás. In: CONGRESSO BRASILEIRO DE GEOLOGIA, 38, Balenário Camboriu, SC, 1994, Resumos Expandidos.... Balenário Camboriu, SBG, v. 1, p.258-259

Oliveira, A. M. \& Jost, H. 1993. Estratigrafia, geoquímica e distribuição dos elementos do grupo da platina (EGP) do complexo de Barro Alto na região de Goianésia, Goiás. I Encontro Brasileiro sobre Minerais do Grupo da Platina, Resumos Exp., 18-19.

Pimentel, M.M.; Fuck, R.A.; Del'Rey Silva, L.J.H. 1996. Dados Rb-Sr e Sm-Nd da região de Jussara-Goiás-Mossâmedes (GO), e o limite entre terrenos antigos do maciço de Goiás e o arco magmático de Goiás. Rev. Bras. Geoc. 26(2):61-70.

Ribeiro Filho, W. \& Teixeira, N. A. 1981. Seqüência vulcano-sedimentar da borda oeste dos complexos de Niquelândia e Cana Brava. Boi. Inf. Núcleo Centro- Oeste, 10:157-177.

Sato, K.; Tassinari C.C.G.; Kawashita, K.; Petronilho, L. 1995. O método Geocronológico Sm-Nd no IG/USPe suas Aplicações. An. Acad. Brás. Ciências, 67(3): 313-336.

Suita, M.T.F.; Kamo, D.L.; Krogh, T.E.; Fyfe, W.S.; Hartmann, L.A. 1994. $\mathrm{U}-\mathrm{Pb}$ ages from the high-grade Barro Alto mafic-ultramafic complex (Goiás, Central Brazil): Middle Proterozoic continental mafic magmatism and Upper Proterozoic continental collision. Abstracts of the Eighth Intern. Conf. on Geochr. Cosmochr. and Isotope Geology (ICOG8). U. S. Geol. Survey, Circ. 1107:309.

Williamson, J.H. 1968. Least Square fitting of a straight line. Can. Jour. Phisics,46: 1845-1847 